\title{
Statistics versus livelihoods: Questioning Rwanda's pathway out of poverty
}

An Ansoms, Esther Marijnen, Giuseppe Cioffo and Jude Murison

Published in Review of African Political Economy, 2016

\begin{abstract}
Recent statistics indicate that poverty in Rwanda decreased impressively between 2006 and 2014. This seems to confirm Rwanda's developmental progress. This paper however argues for a more cautious interpretation of household survey data. We contrast macro-level statistical analysis with in-depth field research on livelihood conditions. Macro-economic numbers provide interesting information; however, differentiated evidence is required to understand how poverty works. On the basis of the Rwandan case study, we conclude that because the political stakes of data collection and analysis are high, cross-checking is crucial.
\end{abstract}

Keywords: Rwanda, poverty, statistics, livelihoods, donor policies, development.

\section{Introduction}

Over the past decade, controversy has emerged on the reliability of national development statistics. Jerven's book 'Poor numbers' (2013A) highlights that many data on African countries are of poor quality, partial and unreliable. The author warns against the tendency to rely on such data for decisions on where to allocate aid on the basis of 'evidence-based policy'. In some African countries, such as Ghana and Nigeria, GDP has consistently been underestimated due to miscalculation (Jerven, 2013B). However, given that GDP estimates rely upon approximations and assumptions, it is also plausible that GDP rates are overestimated. Wallace for example found evidence of GDP manipulation in the case of China, particularly in politically sensitive times (Wallace, 2014). Also for Ethiopia, there are accounts of overestimated GDP figures (IMF, 2013B), interpreted by some as deliberate manipulation by the Ethiopian government.

In response to the renewed debate on the limited reliability of GDP estimates, a rich collection of literature has been reflecting upon the usefulness of other statistics. Data compilation initiatives - such as the Human Development Index or the Multidimensional Poverty Index of UNDP, and the Happy Planet Index from the New Economics Foundation - explore the options of generating multidimensional cross-country datasets. New methods explore the 
reliability of data based on mobile phone communications and airtime credit purchases (Gutierrez et al., 2013). A 2014 OECD report analysed trends in global well-being on the basis of life expectancy, education, personal security and gender inequality. It concluded that these alternative indexes resonate to a more equal world than when considering GDP per capita figures (OECD, 2014).

At national levels, an important alternative data source is the nationally representative household living conditions survey. Poverty and inequality statistics calculated from household surveys are generally considered as robust; and are used to update the reliability of GDP figures (Jerven, 2013B). On the downside, such large-scale surveys are not available every year given their considerable cost. An interesting exercise is thus to compare GDP evolutions with evolutions in poverty and inequality statistics for those years for which survey data are available. In the case of Rwanda, the latest household living conditions survey (EICV4) was conducted in 2013/4 after previous surveys in 2010/11 (EICV3), 2005/6 (EICV2) and 2000/1 (EICV1). The results (see table 1) are illuminating.

High GDP growth rates between 2000/1 and 2005/6 were not accompanied by significant poverty reduction. As a result of high population growth rate, the absolute number of people living in poverty increased (UNDP 2007). This led to questions about the pro-poor character of economic growth. However, between 2005/6 and 2010/11, continued average GDP per capita growth went together with spectacular poverty decrease. In addition, the gini coefficient, a measure of inequality, decreased. The EICV4 results suggest that these trends have continued up to $2013 / 4$. It is to be noted, however, that the methodology for calculating the 2013/14 poverty line differs profoundly from the method used for EICV1, 2 and 3 (a fact recognised by NISR, 2015). As a result of the changed methodology, it is doubtful that the poverty percentage is comparable to past poverty rates; although this is done by the Rwandan government (NISR, 2015).

This paper argues that the sole reliance on large-scale household surveys in order to assess the level of socio-economic progress can be misleading. In fact, while providing comprehensive information on general social trends, large-scale surveys can under-represent or even misrepresent the situation of more marginal groups in society. This is a crucial issue, as the results of large-scale surveys play a pivotal role in determining the allocation of international aid money. Moreover, positive outcomes from large-scale surveys may be used in order to endorse and legitimise government policies, thus minimizing, or at time bluntly overlooking, 
the effects of such policies on population groups whose situation is glossed over in statistical data.

Table 1: Growth - poverty - inequality statistics compared

\begin{tabular}{|c|c|c|c|c|c|c|c|}
\hline & $\begin{array}{l}\text { EICV1 } \\
2000 / 1\end{array}$ & $\begin{array}{l}\text { EICV2 } \\
2005 / 6\end{array}$ & $\begin{array}{r}\text { EICV3 } \\
2010 / 11\end{array}$ & $\begin{array}{c}\text { EICV4 } \\
2013 / 14 \\
(3) \\
\end{array}$ & $\begin{array}{l}2000 / 1- \\
2005 / 6\end{array}$ & $\begin{array}{l}2005 / 6- \\
2010 / 11\end{array}$ & $\begin{array}{c}2010 / 11- \\
2013 / 14(3)\end{array}$ \\
\hline $\begin{array}{l}\text { GDP (mia } \\
\text { frw constant } \\
2011 \text { prices) }\end{array}$ & 1,745 & 2,503 & 3,706 & 4,532 & $\begin{array}{c}\text { Annual } \\
\text { growth of } \\
7.5 \%\end{array}$ & $\begin{array}{c}\text { Annual } \\
\text { growth of } \\
8.2 \%\end{array}$ & $\begin{array}{c}\text { Annual } \\
\text { growth of } \\
6.9 \%\end{array}$ \\
\hline $\begin{array}{l}\text { GDP per } \\
\text { capita (Frw } \\
\text { constant } \\
\text { 2011 prices) }\end{array}$ & 213,343 & 274,410 & 355,377 & 404,229 & $\begin{array}{l}\text { Annual } \\
\text { growth } \% \\
\text { of } 5.2 \%\end{array}$ & $\begin{array}{c}\text { Annual } \\
\text { growth \% } \\
\text { of } 5.3 \%\end{array}$ & $\begin{array}{l}\text { Annual } \\
\text { growth } \% \\
\text { of } 4.4 \%\end{array}$ \\
\hline$\%$ Poor (1) & $58.9 \%$ & $56.7 \%$ & $44.9 \%$ & $39.1 \%$ & $2.2 \% \downarrow$ & $11.8 \% \downarrow$ & $5.8 \% \downarrow(3)$ \\
\hline $\begin{array}{l}\text { \% Extreme } \\
\text { poor }(2)\end{array}$ & $40.0 \%$ & $35.8 \%$ & $24.1 \%$ & $16.3 \%$ & $4.2 \% \downarrow$ & $11.7 \% \downarrow$ & $7.8 \% \downarrow(3)$ \\
\hline $\begin{array}{l}\text { Gini } \\
\text { coefficient }\end{array}$ & 0.507 & 0.522 & 0.490 & 0.448 & & & \\
\hline $\begin{array}{l}\text { Ration of } \\
90^{\text {th }} \text { to } 10^{\text {th }} \\
\text { percentile }\end{array}$ & 7.07 & 7.10 & 6.36 & 6.01 & & & \\
\hline
\end{tabular}

(1) The percentage of poor is based on a poverty line of 64,000 FRW (2001 prices).

(2) Extreme poverty is calculated on the basis of a poverty line of 45,000 FRW (2001 prices).

(3) The methodology for calculating the $2013 / 14$ poverty line differs profoundly from the method used for EICV1, 2 and 3 (a fact recognised by NISR, 2015). As a result of the changed methodology, it is therefore doubtful that the poverty percentage can legitimately be compared to past poverty rates.

Source: for GDP data - World Bank, 2015; for other statistics - NISR, 2012 \& 2012A; NISR, 2015.

In the first part of this paper, we analyse how recent statistics in Rwanda have shaped the public attitude and agenda of the Rwandan government as well as that of its international donors. In the second part of the paper we complement the results of the EICV surveys with our own qualitative research in Rwanda. We mainly focus on the 2005/6 (EICV2) - 2010/11 (EICV3) period as economic development shifted towards being 'pro-poor' according to the statistics. We exploit the explicative power of qualitative data (Olivier de Sardan, 2008) in order to highlight the possible gaps and more questionable results of the EICV surveys.

We base our findings on longitudinal in-depth research. Intensive qualitative data gathering took place in six locations near the same years as the EICV surveys: in 2006/7 (further referred to as AA field notes) and in 2011 (BB field notes). At both times, semi-structured focus groups were conducted with village leaders and with diverse socio-economic categories (between 14 and 20 focus groups per setting, each time including 4 to 7 persons). Questions focused on people's livelihood strategies and on the impact of rural policies. In 2013, we gathered data in two of the six locations (CC field notes). These six settings in the Southern province are not representative for the whole of Rwanda, or even for the Southern province. Indeed, our settings were located in districts where - according to the EICV3 - poverty 
reduction in 2010/11 was limited. ${ }^{1}$ However, the settings represent a variety of rural living environments (better-off versus poorer regions, centrally-located versus extremely remote, more and less fertile). Despite this variety, our findings were quite similar, and we crosschecked with research in two new locations in the Northern Province in 2013 (CC field notes).

\section{The political importance of statistics}

Standardised households surveys are often presented as apolitical and bound by technical procedures. However, their results have political significance, particularly in countries that strongly rely on political and financial support from the international community. Socioeconomic progress is important in enhancing the legitimacy of the recipient government; while donors need 'success-stories' to legitimise their expenditures in development cooperation. Therefore, statistical data and their interpretations should be analysed in light of the political stakes involved.

Both the 2005/6 and 2010/11 EICV surveys were undertaken to provide input to the Economic Development and Poverty Reduction Strategies (EDPRS-I and EDPRS-II). The Rwandan government launched these strategies to achieve its Vision 2020 objectives. ${ }^{2}$ As mentioned above, poverty reduction was limited over the 2000/1-2005/6 period when the first Poverty Reduction Strategy (PRSP) was implemented. The Rwandan government's explained that the first PRSP "was elaborated in a post-conflict environment where the main emphasis was on managing a transition from emergency relief to rehabilitation and reconstruction" (GoR, 2012: 2). Donors, however, became increasingly critical of the government's rather exclusive focus on economic growth, and criticised the deepening of existing gaps ${ }^{3}$. In 2007 , UNDP launched a critical report, 'Turning Vision 2020 into Reality: From recovery to sustainable human development' (UNDP, 2007), which was received negatively by the government. The report delved extensively into the problem of inequality, and warned "extreme inequality can weaken political legitimacy and corrode institutions, leading to higher political instability caused by popular movements of discontent in countries with large gaps between the rich and the poor." (UNDP, 2007:18-21)

As Rwanda was - and continues to be - heavily dependent upon international donors (see table 2), the increased donor focus on inequality was problematic for the Rwandan government. Rwandan political elites had gained legitimacy within the donor community on the basis of 
Rwanda's high technocratic governance standards (Reyntjens, 2013). By 2012, it was therefore crucial for the Rwandan government to prove that their development model was working.

Table 2: Net official development assistance and aid received by Rwanda

\begin{tabular}{|l|c|c|c|c|c|c|c|c|c|c|}
\hline constant 2012) & $\mathbf{2 0 0 4}$ & $\mathbf{2 0 0 5}$ & $\mathbf{2 0 0 6}$ & $\mathbf{2 0 0 7}$ & $\mathbf{2 0 0 8}$ & $\mathbf{2 0 0 9}$ & $\mathbf{2 0 1 0}$ & $\mathbf{2 0 1 1}$ & $\mathbf{2 0 1 2}$ & $\mathbf{2 0 1 3}$ \\
\hline million US\$ & 585 & 670 & 679 & 754 & 932 & 961 & 1069 & 1235 & 879 & 1075 \\
\hline
\end{tabular}

Source: World Bank (2015) World Bank Development Indicators, World Bank, online at databank.worldbank.org [date last access: 9 November 2015].

When the EICV3 report came out, the announced poverty figures (cfr. table 1) were close to the targets the Rwandan government had proposed in its 2007 EDPRS-I strategy ${ }^{4}$. In the foreword of the EICV3 report, the Minister of Finance and Economic Planning stated "the[se] milestones are indeed a testament to the guidance and support of the top leadership in the country in the fight against poverty" (NISR, 2012: 3). President Kagame, in his foreword of the EDPRS-II report, lauded the achievements and highlighted that "our progress strengthens the belief that our development ambitions towards the Vision 2020 can be achieved with our concerted efforts" (GoR, 2012: viii).

The results of EICV3 were presented in February 2012, but the euphoric news was quickly overshadowed by the creation of the M23 rebel group in eastern Democratic Republic of the Congo (DRC) in April 2012. Rwanda faced severe criticism from the international community for its role. Various donors 'froze' part of their aid, resulting in a decrease in overall aid figures in 2012 (see table 2). By November 2013, however, the 'M23 problem' was contained. Many donors resumed their aid and quickly picked up again on the impressively improved figures.

In the academic literature that appeared around that time, Rwanda was described as a 'developmental patrimonial state' of which the 'politically inspired economic activism' might be a model for other African States (Booth \& Golooba-Mutebi, 2012). Reports from the World Bank and IMF pointed to positive achievements in terms of economic growth, poverty reduction, improvements in business climate, and in public service delivery (World Bank, 2013; IMF, 2013). DfiD, in its operational plan 2011-2015, referred to the 12 percent point poverty decrease as proof of Rwanda being on track to meet the MDGs (DFID 2012). SIDA, the Swedish Development Agency, compared Rwanda's achievements - as an exceptional African success story - to Thailand, China and Vietnam ${ }^{5}$. Participant observation of one of the 
authors within the European External Action Service (EEAS) in 2012 revealed that the positive survey results were used internally in the EU to counter expressions of concerns about the authoritarian nature of the government and military involvement in eastern DRC (author reference purpose). Overall, the results of the 2010/11 survey were welcomed as the much-needed scientific proof of a successful developmental path and provided donors with a political justification to allocate aid while ignoring criticism on Rwanda's limited space for political freedom.

Recently, the release of the 2013/14 EICV4 results led to controversy on the methodology used for recalculating the poverty line - and thus, on the comparability of the data between EICV3 (2010/11) and EICV4 (2013/14). Whereas the Rwandan government's official report announced a poverty reduction of $6 \%$ (based on a recalculated poverty line), Reyntjens came to an estimate of a $6 \%$ poverty increase between 2010/11 and 2013/14 (Reyntjens, 2015). The story was picked up by France 24 (Germain, 2015). The National Institute of Statistics of Rwanda refuted the allegations of manipulating its poverty statistics, claiming that the 'changes to the ratio of products in the food basket [on the basis of which the poverty line is calculated] are made following a rigorous methodological process' (NISR, 2015). However, they did not respond to the technical aspects of Reyntjens' arguments in relation to the comparability of the poverty lines. Yet, the Rwandan government was backed up by some of its major donors. A DFID spokesperson said, 'we believe the revision of the methodology used to estimate poverty levels for the EICV4 poverty survey was justified' (Germain, 2015). The NewTimes cites IMF Mission Chief Redifer saying, 'we have no reason to doubt the numbers' (Agutamba, 2015).

Overall, it is clear that the EICV surveys have a major importance to both Rwandan policy makers as well as international donors in evaluating and justifying policy implementation and aid effectiveness. And indeed, these large-scale statistical surveys provide interesting information. However, they tend to ignore the diverse accounts of people's livelihood strategies, and turn a blind eye to life experiences regarding public policies. Although the controversy around the 2013/14 EICV4 dataset is much stronger, we have decided to focus on enriching statistical material from 2005/6 (EICV2) and 2010/11 (EICV3) with in-depth qualitative data gathered around that same period. 


\section{Confronting macro-economic data with every-day poverty: Sampling problems}

In a critical analysis of household survey data, Carr-Hill notices that surveys typically underrepresent six vulnerable subgroups: (1) the homeless, (2) those in institutions, (3) mobile, nomadic or pastoralist populations, (4) those in fragile disjointed households, (5) slum populations, and (6) areas posing security risks. According to Carr-Hill (2014:136), "those six subgroups constitute a large fraction of the 'poorest of the poor'", and their omission in the 'denominator' is likely to insert substantial biases in poverty assessments. This argument might also be relevant when considering the Rwandan context. It is quite likely that homeless, mobile populations, or those illegitimately living in slums at the borders of Kigali, are underrepresented in the overall dataset. However, if this statistical problem would explain part of the spectacular poverty decrease over the 2005/6-2010/11 period, then the denominator problem should be more outspoken for EICV3 then for EICV2.

We have reason to believe that this is the case. In fact, we found a strange anomaly in the distribution of population by age group in EICV3 (2010/11), compared to EICV2 (2006/7). The samples of both EICVs should be representative for the total population. And given that this period was not characterised by major societal upheaval, we would not expect significant changes in the age structure of the population, except maybe in the youngest and eldest groups. Furthermore, it would be logical that a particular age group in 2010/11 would contain approximately the same proportion of people as the lower age group in 2005/6.

Table 3: Distribution of population by age group on basis of EICV sample extrapolations

\begin{tabular}{|cc|c|cc|}
\hline \multicolumn{2}{|c|}{ EICV2 } & & \multicolumn{2}{|c|}{ EICV3 } \\
\hline $\begin{array}{c}\text { Age groups } \\
\text { 2005/6 }\end{array}$ & $\begin{array}{c}\text { People } \\
\mathbf{2 0 0 5 / 6}\end{array}$ & $\begin{array}{c}\text { Change } \\
\mathbf{2 0 0 5} / 6-\mathbf{2 0 1 0} / \mathbf{1 1}\end{array}$ & $\begin{array}{c}\text { People } \\
\mathbf{2 0 1 0} / \mathbf{1 1}\end{array}$ & Age groups 2010/11 \\
\hline Total & $\mathbf{9 . 4 9 1 . 0 0 0}$ & & $\mathbf{1 0 , 7 6 2 , 0 0 0}$ & Total \\
\hline & & & $1,630,000$ & $0-4$ \\
$5-4$ & $1,561,000$ & $0.70 \%$ & $1,572,000$ & $5-9$ \\
$10-14$ & $1,331,000$ & $5.48 \%$ & $1,404,000$ & $10-14$ \\
$15-19$ & $1,232,000$ & $-2.19 \%$ & $1,205,000$ & $15-19$ \\
$20-24$ & $1,203,000$ & $-14.71 \%$ & $1,026,000$ & $20-24$ \\
$25-29$ & $1,002,000$ & $-11.68 \%$ & 885,000 & $25-29$ \\
$30-34$ & 687,000 & $-5.68 \%$ & 648,000 & $30-34$ \\
$35-39$ & 492,000 & $2.44 \%$ & 504,000 & $35-39$ \\
$40-44$ & 390,000 & $6.15 \%$ & 414,000 & $40-44$ \\
$45-49$ & 400,000 & $-7.75 \%$ & 369,000 & $45-49$ \\
$50-54$ & 342,000 & $-2.05 \%$ & 335,000 & $50-54$ \\
$55-59$ & 266,000 & $-6.39 \%$ & 249,000 & $55-59$ \\
$60-64$ & 170,000 & $-5.88 \%$ & 160,000 & $60-64$ \\
$65-\ldots$ & 123,000 & & 361,000 & $65-\ldots$ \\
\end{tabular}


Source: Compiled from data in National Institute of Statistics of Rwanda (2012) The Third Integrated Household Living Conditions Survey (EICV3): Main Indicators Report, Kigali, NISR, p.30.

However, when we compare youth age groups on the basis of EICV sample extrapolations (NISR, 2012A), we notice some strange anomalies (see table 3). The 20-24 age group in 2010/11 contains almost $15 \%$ less people than the 15-19 age group in 2005/6. Similarly, the 25-30 age group by 2010/11 contains almost $12 \%$ less people than the 20-24 age group in 2005/6. In total, we are talking about 294,000 'missing youth' not taken into account in the $2010 / 11$ EICV sample ${ }^{6}$. It is as if $15.6 \%$ of male youth and $11.3 \%$ of female youth have disappeared from the 2010/11 sample in comparison to 2005/6. Three questions then arise. First, what could be the poverty profile of these 'missing youth'? Second, which factors could explain their omission in the survey sample? And third, what impact could this statistical anomaly have upon the reported 2006-2011 poverty decrease?

Let us start with the first question. According to the household survey data, the 2010/11 poverty rate among youth (age 14-35) of 38.5\% is significantly lower than the overall poverty rate of 44.9\% (NISR, 2012B). Our qualitative research, however, suggested the opposite: increasingly problematic living conditions for a majority of Rwandan youth. First of all, land scarcity hugely reduced rural youth's chances to generate an income within the agricultural sector. According to the EICV surveys, cultivated land per household decreased from 0.75 hectares in 2005/6 to 0.59 hectares in 2010/11. By 2010/11, over 83\% of households disposed of less than one hectare, in comparison to about 75\% in 2005/6 (NISR, 2012C). Moreover, land is highly unequally distributed between socio-economic categories and age groups. Whereas older farmers still hold on to their historic property, many young farmers are not capable of inheriting or buying enough land to sustain their family's needs (Musahara and Huggins, 2004, AA field notes, 2006/7). They have to look for other kinds of jobs on the daily labour market where employment opportunities for young unskilled labour force are limited. We will come back to this point later in the paper.

Another important problem for youth relates to the Rwandan government's villagisation policy. Customarily, people do not live in clearly identifiable villages but live scattered on the hills (De Lame, 2005). Traditionally, young men would ask their father for 'their' part of the family's land in order to build their house and cultivate their own plot(s). Owning a house allowed them to make the transition to 'adulthood' (Sommers, 2012). However, the Rwandan government envisions a modern spatial organisation. Since 1994, Rwandan policy makers have attempted to resettle households in grouped settlements (for a critique, see Newbury, 
2011; Leegwater, 2011). When in the early 2000s, civil society, scholars, and later international donors objected to the negative impact of this policy, it was partially abandoned. However, in the 2010s a 'mild' version of the centralisation approach has reappeared: newly established households are obliged to settle at specific sites within centralised communities (Ansoms and Rostagno, 2012). Next to culturally based objections, there are two main economic problems for young households. First, the cost of land in these 'centres' is often very high. Second, houses have to be build according to costly standards (with a separate kitchen, stable and toilet and with proper roofing) (BB field notes, 2011). As a result many young men lack the means to build their own house. They cannot marry, and as a consequence, they cannot start their 'adult' life. This phenomenon is closely linked with the increasing incidence of unmarried young mothers, resulting in growing social exclusion and marginalisation (BB field notes, 2011; Sommers, 2012; Ansoms and Rostagno, 2012). A significant portion of these young people, especially those from poorer families, are 'stuck' in their status as 'youth' because they do not have the necessary means to start their adult lives (Sommers, 2012).

So our qualitative analysis suggests that poverty among youth could be more prevalent than what EICV surveys suggest. But this brings us to our second question: why would youth and particularly poor rural youth - have been more under-represented in the 2010/11 survey than in the 2005/6 survey? There are two plausible and complementary explanations. First, interviewed household heads might not have mentioned their (near-to-) adult sons and daughters as part of the household because they had migrated. Indeed, migration is definitely a strategy for young people to search for income-generating opportunities, but also a way-out to escape from the social stigma of lacking the means to build a house (Sommers, 2012). Normally, those absent at the time of the 2010/11 survey should still have been included in the sample, given that the 2002 Household Census was updated for the EICV3 locations. However, from our qualitative research, we noticed that local authorities often do not consider migrants as part of the local community. For example, migrants were very often not included in the participatory mapping exercises that were undertaken as part of the Ubudehe project in all Rwandan villages at several points in time (AA and BB field notes, 2006/7, 2011). Young poor migrants might thus have been underrepresented in the EICV3 sample.

The second possibility is that household heads did not report the presence of their (near-to) adult sons and daughters because they were officially no longer supposed to be part of the parents' households. In our own research, we frequently came across young adults 
illegitimately 'occupying' a side building of their parents' house, with or without their permission (BB field notes, 2011). Such - generally poor - households could not be officially registered because they had ignored grouped settlement regulations, and were thus not included in the EICV3 sample.

Overall, the problem of 'missing youth' seems an important issue. However, the impact of this statistical anomaly on poverty reduction estimates is likely limited. Even if we would assume that all 294,000 missing youth were poor - which is highly unlikely - the impact on the $2010 / 11$ poverty rate ( $46.4 \%$ instead of $44.9 \%$ ) would have been minor. At the same time, the issue of 'missing youth' might reflect more fundamental problems with underrepresentation of vulnerable subgroups in the 2010/11 survey. However, this cannot be verified on the basis of the available information.

\section{Erroneous answers and misreporting}

Although the sample anomaly described above had only a minor impact on overall poverty estimates, other factors might have led to an overestimation of poverty reduction. Scholarly research on the effect of non-response ${ }^{7}$ in household surveys (see e.g. Bethlehem et al., 2011) is abundant, but research on response effects and strategic answering in household surveys is scarcer. Nevertheless, interviewees' answers may significantly divert from reality for several reasons.

When considering the cognitive aspects of survey methods, Schwartz (2007) distinguishes several steps. Respondents first have to interpret the question. They then have to recall the relevant information with regards to a particular reference period and measurement unit. Nondeliberate distortions at each of these steps may take place. In addition, respondents may edit their answer for reasons of 'social desirability' and 'situational adequacy'. These 'response effects' insert significant bias in the survey data (Schwartz, 2007).

A well-known phenomenon in nearly every household survey is the discrepancy between consumption and income estimates. Households generally underestimate their income (Deaton, 1997), and sometimes overestimate their consumption - particularly for food items (for more details, see FAO, 2008). Under reporting of income may be the result of fallacious memory, but it may also be a deliberate strategy to avoid taxes (see e.g. Hurst et al., 2014). 
Or, it may result from under-representation of higher income groups in household survey samples (see e.g. Wang and Woo, 2011), leading to lower average incomes.

Similar distortions occur with regards to other variables. Our own experience in Rwanda suggests that respondents are reluctant to provide answers on questions regarding productive resources (i.e. ownership of land, variable capital, labour productivity and agricultural output) (AA and CC field notes, 2006/7 and 2013). Such information is sensitive, and moreover the respondent may be suspicious of the researcher's motivations (Ansoms, 2012). However, whereas standardised, large-scale surveys rely on a 'one-time' approach (all information is collected at one moment in time), qualitative and mixed research is more iterative in nature. This allows for comparisons of respondents' answers over different moments in time, and allows the respondent to re-evaluate and re-consider his or her answers.

Question is now whether such 'response effects' in the case of Rwanda's EICV surveys partly explain the reported 2005/6-2010/11 poverty decrease. Did respondents in 2010/11 have reasons to overestimate certain achievements, and more so than in 2005/6? Our micro-level field research suggests that this is the case. Over the last couple of years, Rwanda has been transformed into a target-oriented society. Since 2006, authorities at district level have to commit themselves to a system of 'performance contracts' (imihigo). These contracts between the president, line ministries and local authorities bind the district authorities to reaching particular targets set in line with national development priorities (Versailles, 2012; Ingelaere, 2010; Thomson, 2013). The contracts generally leave little room for local authorities to set their own policy objectives (Chemouni, 2014; Gaynor, 2014). The goals can be multiple: reaching production targets for particular crops, making sure that the local population participates in health insurance schemes, reinforcing particular settlement schemes, imposing decent housing standards, etc. (BB field notes, 2011).

This target-orientation seems to translate into tangible results. Through qualitative data gathered in 2011, Ingelaere (2014) reports how the population experienced an improvement in the delivery of basic services. DHS data indicate that improved service delivery led to a sharp improvement in health statistics between 2005 and 2010 (NIRS, 2012E, for a discussion, see McKay and Verpoorten, forthcoming). However, the follow-up of local imihigo performance contracts is very strict. An evaluation team composed of representatives from several line ministries score each district every semester on the basis of targets reached. Repeated underperformance may lead to firing the district mayor (Versailles, 2012). In fear of these 
sanctions, it occurs regularly that local officials rigidly and blindly implement the set targets, irrespectively of the possible negative consequences for the local population (BB and CC field notes, 2011 and 2013). Ingelaere highlights how in the imihigo system, "the chain of accountability goes upwards towards higher authorities and not downwards towards the population" (Ingelaere, 2010: 288). Moreover, over the years, pressure to meet these targets has increased, so that "local officials often cut corners to meet the development commitments” (Thomson, 2013). Also the New Times reported on local authorities who manipulated data in order to show to the national government that they reached incredible levels of progress (Rugira, 2014).

This awareness-raising about the importance of reaching targets definitely reached the ground. Our micro-level interviews in 2011 and 2013 showed that local farmers were very aware of authorities' expectations. Households are supposed to shift from subsistence to market-led commercially oriented agriculture in line with the Crop Intensification Program, launched in 2006/2007. They are supposed to adopt mono-cropping techniques on consolidated land, and to cultivate particular market-oriented crops such as maize, rice, beans and cassava. And most of all, they are supposed to produce more (BB and CC field notes, 2011 and 2013; Huggins, 2014; Huggins, 2013, Cioffo and Ansoms, forthcoming). In fact, the 2005 land law gives district authorities the responsibility to safeguard that all land is well managed and productively exploited, if not the farmer may lose access (GoR, 2005). Households are even actively inserted into the accountability chain (cfr. Ingelaere, 2010). In 2011, we already noted that in certain settings, individual households had been obliged to sign household-level performance contracts (BB field notes, 2011). This is part of a broader strategy - officially launched by the Minister of Local Affairs in February 2012 - to involve all households in setting up a performance contract notebook. In this notebook, households are to commit themselves to their own development targets, in line with local and national development priorities.

However, our research material also revealed that authorities' expectations often did not match local realities on the ground. Many of our interviewees strongly resented the imposition of preferential market-oriented crops per region, and attempted to circumvent these obligations by secretly cultivating their preferred crops (BB field notes, 2011; see also Cioffo and Ansoms, forthcoming with regards to enforced maize and wheat production, Van Damme et al., 2014 with regards to beer versus cooking and dessert banana type preferences; Huggins, 2013 on forced pyrethrum production). Farmers from various settings indicated that crop 
harvest in marshland cooperatives ${ }^{8}$ had been disappointing for several years, and that incomes from crop sales though such cooperatives were often problematically low ( $\mathrm{BB}$, field notes, 2011; CC field notes, 2013, see also author reference). Smallholder farmers reported lower food security as a result of a loss of ownership over their productive process. Land use consolidation ties farmers into dynamics of commercial agriculture that regularly result in food security failures for the poorest households (CC field notes, 2013, see also author reference). Farmers reported their frustration having been obliged to sell part of their assets (mostly goats) in order to pay their health insurance (BB field note, 2011).

At the same time, interviews with Rwandan farmers suggest that reticence to discuss issues of inequality with local-level authorities is widespread. Farmers highlighted the political weight of imihigo contracts on local authorities, and pointed to the way in which imihigo tie the whole population to the development targets. When discussing the forceful sale of household cattle for the payment of a health insurance, one focus group participant stated: "it is because of imihigo, it is because of these objectives they have to reach... if people do not have a health insurance, they do not respect government plan and, they would not reach their objectives. That's why they push us" (CC, focus group September 2013, Southern Province). The situation appeared equally clear to another participant: "There are often meetings at the district office, and it is the executive secretary in the sector that goes there. They decide the imihigo there: 'we are going to do this, we will have that many health insurances'. Then they talk to local authorities and they say: 'you should have that many health insurances, that much this and that". And if we don't have the money, they will even sell our bean seeds to buy a health insurance. And that's the way it is, like it or not" (ib.). Similar accounts were gathered with regards to the necessity to reach certain production targets in line with regional and national priorities.

It is in such context that interviewees are confronted with a government-related surveyor who questions the interviewee on the achievements of its household. Those same interviewees have been massively sensitised and pushed by local authorities to reach certain targets. “[W]hen people are sensitized”, Purdekova (2012: 16) writes, "they are handed 'indisputably' positive guidelines; these are not to be discussed". Such 'guidelines' may concern the obligation to join a marshland cooperative that aims for particular production targets, the importance of growing maize or wheat instead of sorghum for food security or to use industrial fertilizers, often regardless of households economic capacity to adopt such guidelines. "Ultimately, the attempt is not to make people 'believe' all the messages as 
sensitisation cannot make this possible. Rather, the aim is for people to possess key information and to know what is expected of them" (ib.). Efforts of sensitisation in relation to the central developmental objectives have clearly intensified over the last decade. For this reason, we consider it likely that interviewees' considerations of social desirability and situational adequacy - leading to an exaggeration of their performance - played a role in their responses to the EICV3 survey.

\section{Strategic interpretation of data}

A final problem with EICV3 is the way in which particular data have been interpreted. According to the EICV3 report, the increased agricultural production and the increased commercialisation of agriculture were two among three factors explaining the spectacular decrease in poverty figures (NISR, 2012). Indeed, it goes beyond doubt that the agricultural yields in 2010/11 were higher than in 2005/6. However, part of the explanation lies in the fact that agro-climatic conditions were better in 2010/11 (McKay and Verpoorten, forthcoming). The agricultural performance in 2005/6 was severely affected by draught (see e.g. FEWS, 2005 and 2006); whereas 2010/11 was a good agricultural season. However, the EICV3 report does little to explain the importance of this factor in the increase in agricultural output, thus overlooking possibly important nuances (McKay and Verpoorten, forthcoming).

Another factor highlighted in the EICV3 report to explain poverty reduction, is the substantial creation of off-farm jobs. According to the surveys, more than half a million additional jobs were created in the off-farm sector and over 130,000 jobs in the farm sector over the 2005/6 2010/11 period (see table 4). According to EICV3 data, over three quarters of people employed in the off-farm sector are non-poor, whereas this is only slightly over half in the farm sector (see table 5). Moreover, off-farm jobs tend to (almost) full-time employment, whereas farm jobs are only part-time employment ${ }^{9}$. The EICV3 report notes that "there has been substantial creation of jobs, predominantly in non-farm activities, over the past five years. This was almost certainly an important factor contributing to poverty reduction" (NISR, 2012: 11).

Where do such relatively attractive off-farm jobs come from? At first sight, one might say that this labour force was absorbed through an increase in formal enterprise registration. Between 2007/8 and 2010/11, the total number of registered enterprises rose by almost 70 (cfr. table 6; Gökgür, 2012). The Rwandan Private Sector Federation has intensely invested in facilitating 
'doing business' in Rwanda. These efforts are reflected in the improvement of the Rwandan performance in the World Bank's Doing Business Report, in which Rwanda stands out as top reformer in Sub-Saharan Africa. Rwanda performs particularly well in terms of easiness to start a business, to register property, and to access credit (World Bank, 2016).

Table 4: Change in Farm and Non-Farm Employment between 2001/2 and 2010/11

\begin{tabular}{|l|cc|cc|cc|}
\hline & EICV1 & & \multicolumn{2}{|c|}{ EICV2 } & & EICV3 \\
& $\mathbf{2 0 0 1 / 2 0 0 2}$ & & $\mathbf{2 0 0 5 / 6}$ & & $\mathbf{2 0 1 0 / 1 1}$ \\
\hline & people & $\mathbf{\%}$ & people & $\mathbf{\%}$ & people & \% \\
\hline Farm employment & $\mathbf{3 , 4 2 1 , 0 0 0}$ & $88.6 \%$ & $\mathbf{3 , 4 1 7 , 0 0 0}$ & $79.5 \%$ & $\mathbf{3 , 5 5 3 , 0 0 0}$ & $71.6 \%$ \\
-independent farmers & $3,278,000$ & $84.9 \%$ & $3,065,000$ & $71.3 \%$ & $3,063,000$ & $61.8 \%$ \\
-wage earners from farming & 143,000 & $3.7 \%$ & 352,000 & $8.2 \%$ & 490,000 & $9.9 \%$ \\
Non-farm employment & $\mathbf{4 4 2 , 0 0 0}$ & $11.4 \%$ & $\mathbf{8 8 3 , 0 0 0}$ & $20.5 \%$ & $\mathbf{1 , 4 0 6 , 0 0 0}$ & $28.4 \%$ \\
-independent non-farmers & 134,000 & $3.5 \%$ & 347,000 & $8.1 \%$ & 479,000 & $9.7 \%$ \\
-wage earners outside farming & 284,000 & $7.4 \%$ & 468,000 & $10.9 \%$ & 838,000 & $16.9 \%$ \\
-un-paid non-farming & 24,000 & $0.6 \%$ & 68,000 & $1.6 \%$ & 89,000 & $1.8 \%$ \\
\hline TOTAL EMPLOYMENT & $\mathbf{3 , 8 6 3 , 0 0 0}$ & $100.0 \%$ & $\mathbf{4 , 3 0 0 , 0 0 0}$ & $100.0 \%$ & $\mathbf{4 , 9 5 9 , 0 0 0}$ & $100.0 \%$ \\
\hline
\end{tabular}

Source: Compiled from data in National Institute of Statistics of Rwanda (2012) The Third Integrated Household Living Conditions Survey (EICV3): Main Indicators Report, Kigali, NISR, p. 93.

Table 5: Poverty status by main job in 2010/11

\begin{tabular}{|l|ccc|c|}
\hline & $\begin{array}{c}\text { Extremely } \\
\text { poor }\end{array}$ & Poor & Non-poor & $\begin{array}{c}\text { Total } \\
\text { people }\end{array}$ \\
\hline Farm employment & $\mathbf{2 5 . 0 \%}$ & $\mathbf{2 3 . 0 \%}$ & $\mathbf{5 2 . 1 \%}$ & $\mathbf{3 , 5 5 3 , 0 0 0}$ \\
-independent farmers & $22.9 \%$ & $22.9 \%$ & $54.3 \%$ & $3,063,000$ \\
-wage earners from farming & $38.1 \%$ & $23.7 \%$ & $38.2 \%$ & 490,000 \\
Non-farm employment & $\mathbf{1 1 . 3 \%}$ & $\mathbf{1 1 . 7 \%}$ & $\mathbf{7 7 . 1 \%}$ & $\mathbf{1 . 4 0 6 . 0 0 0}$ \\
-independent non-farmers & $10.4 \%$ & $13.3 \%$ & $76.3 \%$ & 479,000 \\
-wage earners outside farming & $11.4 \%$ & $10.9 \%$ & $77.8 \%$ & 838,000 \\
-un-paid non-farming & $15.3 \%$ & $10.4 \%$ & $74.3 \%$ & 89,000 \\
\hline TOTAL EMPLOYMENT & $\mathbf{2 1 . 1 \%}$ & $\mathbf{1 9 . 8 \%}$ & $\mathbf{5 9 , 1 \%}$ & $\mathbf{4 , 9 5 9 , 0 0 0}$ \\
\hline
\end{tabular}

Source: Compiled from data in National Institute of Statistics of Rwanda (2012) EICV3 Thematic Report Economic activity, Kigali, NISR, p. 38.

However, the spectacular increase in the total number of formally registered establishments did not result in a high job increase in the formal sector (only 84,130 additional jobs). ${ }^{10}$ By 2010/11, formal off-farm employment represented less than $20 \%$ of all off-farm jobs and only $5 \%$ of all employment (see also Gökgür, 2012). The informal sector however employed an impressive 1,146,791 people, either as wage earners or as independents. Did for some reason the Rwandan government's business incentives for the formal sector result in a boost of activity in the informal sector? Whereas the measures for business facilitation have impressed international donors, these policies were tailor-made for large-scale, capital-intensive projects inserted into the formal economy. Our micro-level evidence indicates that the climate became much more difficult for small-scale investment from the side of local entrepreneurs inserted in the informal economy (author reference). Let us consider a couple of examples. 
Table 6: Employment generated by establishments/enterprises (2008-2011)

\begin{tabular}{|l|ccc|}
\hline (number of people) & $\mathbf{2 0 0 7 / 8}$ & $\mathbf{2 0 1 0 / 1 1}$ & Change \\
\hline Number of establishments/enterprises & 72,994 & 123,526 & $+50,532$ \\
Average worker by establishment/enterprise & 2.7 persons & 2.3 persons & \\
\hline Number of persons employed in enterprises & 197,816 & 281,946 & $+84,130$ \\
of which agriculture, forestry, fishing & $*$ & 22,737 & \\
of which off-farm & $*$ & 259,209 & \\
\hline Total Non-Farm Employment & $1,092,200^{\circ}$ & $1,406,000^{\circ}$ & \\
formal off-farm employment & $*$ & 259,209 & \\
informal off-farm employment & $*$ & $1,146,791$ & \\
\hline
\end{tabular}

Note: The establishment/enterprises include private enterprises, party-statals, cooperatives, non-profit organizations, and public sector or mixed enterprises.

* The original data for 2007/8 were no longer available since the Enterprise Survey Report has been taken off the Private Sector Federation's website shortly after the publication of a critical discussion paper (Gökgür, 2012).

- These data were already presented in the previous table. Total informal off-farm employment is then the result of total non-farm employment (reported in the EICV3 report) minus formal off-farm employment (reported in the 2011 establishment census).

Source: Compiled from data provided in Enterprise Survey 2008 and Establishment Census 2011, Private Sector Federation, Rwanda; published in Gökgür, G. (2012) 'Rwanda's ruling party-owned enterprises: Do they enhance or impede development?', IOB Discussion Papers 2012.03, Antwerp: Institute of Development Policy and Management.

One of the sectors in which jobs could have been created, is in the manufacturing of rural products into higher value products. This was in any case one of the objectives of the 2007 EDPRS-I. Over the last years, older transformation units have indeed been upgraded (e.g. factories for coffee and tea), while other facilities have been developed. However, the net gains of the creation or rehabilitation of such facilities are often limited. In 2013, we conducted an in-depth study of three of such facilities in both Southern and Northern province (a tea factory, a coffee factory, and a cassava flour factory). In all three cases, local farmers had been forced into explicit or implicit contract farming schemes, obligatorily selling their production to the factory. This gave the factory's management significant power to reduce the prices paid to local farmers. Moreover, employment opportunities within the processing facilities were limited, and wages paid were relatively low in comparison to other off-farm jobs in the informal sector (CC field notes, 2013; also see author reference).

Within the sector of transport and trade, policy initiatives inserted complications for informal businesses. Street vending in Kigali has been prohibited (Sommers, 2012). Petty markets have been relocated at significant distance from the centre. But also in rural areas, petty trade became highly regulated as a result of policy makers' attempt to formalise the supply chains of local markets. Traders need an official licence to operate on the market. We had several accounts of farmers being fined highly for selling produce informally along the roadside. Farmers are increasingly dependent upon fewer traders operating at a larger scale, and are obliged to accept lower prices because they lack alternative options to bring their produce to 
the market. A lot of people previously active in trading goods have been obliged to cease their activity because they lack the necessary means to formalise their enterprise (BB, field notes, 2011). Another important informal labour-absorbing activity, artisanal brick and tile-baking, has been prohibited. Modern ovens are operated by officially registered entrepreneurs or cooperatives, but absorb much less labour and pay lower salaries (author reference).

When bringing all together, we are left with a confusing puzzle. According to EICV3, there was spectacular job creation mainly in the off-farm sector, and these jobs resulted in higher living standards (given the lower poverty figures of people employed in off-farm jobs). At the same time, we were able to demonstrate that formal job creation was limited (on the basis of the government's establishment census figures). Moreover, our own in-depth qualitative research suggests that the policy measures complicated the functioning of the informal sector. Hence, the question of how substantial job creation was realised over the 2005/6-2010/11 period and how this could have been a major factor in poverty reduction, remains unclear.

\section{Conclusion}

Standardised, large-scale surveys have become the norm when evaluating the performance of countries' policies and of development aid allocation. The process that leads to the production of such surveys is presented as technically-bound, apolitical, and objective. However, this paper has demonstrated that a complicated reality exists behind the neutral façade of largescale samples.

This is clear in the case of Rwanda. Recent messages coming from Rwanda are euphoric. The statistics indicate steady economic growth rates and decreasing levels of poverty and inequality. However, McKay and Verpoorten (forthcoming: 16) found for Rwanda that "subjective measures of well-being do not necessarily align well with objective measures of well-being; and that the mismatch may be considerable in Rwanda as a result of rapid and profound economic and social transformations". Indeed, quantitative surveys and qualitative assessments measure a different concept of poverty and well-being. In this article, we also argue for a more cautious analysis of the available statistical data, because when nuancing nationally representative statistics with the results from longitudinal in-depth field research we identify three main problems in the $2005 / 6$ - 2010/11 poverty assessment. 
First, we noted that about 294,000 'missing youth' were not taken into account in the 2010/11 EICV sample. They were likely left out of the sample after migrating or due to their transformation into 'illegitimate' non-registered families. We also pointed to youth's problematic living conditions as a result of land scarcity, limited job availability outside the agricultural sector, and new housing regulations. Despite the fact that the omission of 294,000 young people - likely the poorest among them - only had a limited impact upon overall poverty estimates, these missing youth may represent a larger problem of 'invisible' vulnerable categories in household surveys.

Two other problems are more fundamental. First, there is the mismatch between authorities' pressures to reach performance targets at all cost, and the realities on the ground. Smallholder farmers face difficulties inserting themselves into forced production and commercialisation schemes, or to align to target-oriented policy objectives. They feel the pressure of authorities' targets through explicit and implicit threats when falling short of expectations. At the same time, the public space to call into question certain policies is extremely limited. Interviewees' considerations of 'social desirability' and 'situational adequacy' may have influenced the answers given to a government-related surveyor, which could have resulted in overestimated production figures.

A final issue lies in the interpretation of the EICV statistics. The EICV report does not take into account how agro-ecological variations might explain part of the increased agricultural performance in 2010/11. Another problem is the mismatch between EICV statistics indicating massive high-value off-farm job creation, and the observations from in-depth longitudinal research indicating a deteriorating climate for small-scale off-farm investment in the informal economy.

Indeed, Rwanda is not the only country in which a conflict between qualitative and quantitative analysis of poverty change occurs. Appleton and Booth (2001) for example have come to a similar conclusion when confronting participatory and survey-based approaches to poverty monitoring in Uganda. We do however highlight the importance of considering the political value of statistics to obtain a more in-depth understanding of Rwanda's pathway out of poverty. Given the shortcomings of national household datasets, it is thus crucial to bring the findings of in-depth qualitative research back into the picture in order to improve the poverty-reduction capacity of public policies. 
Acknowledging the shortcomings of standardised large-scale surveys is not the equivalent of throwing away the baby with the bathwater. Rather, it is an acknowledgement of the complicated nature of social life, and of surveying as a social activity that is influenced by power relations as well as by existing inequalities and biases both on the side of the researchers and the respondents. Because of these reasons, a more complex approach by government surveyors is needed, combining the explanatory power of different research techniques. At the same time, donors and policy makers should move beyond accepting largescale surveys at face-value, as a more critical outlook may benefit both the effectiveness of aid and the interests of those whose voice is often ignored by large-scale statistics. These conclusions seem of crucial value for continued work on the controversy raised in relation to the EICV4 2013/14 results.

\section{Endnotes}

\footnotetext{
${ }^{1}$ McKay and Verpoorten (forthcoming) have calculated changes in poverty between 2005/6 and 2010/11 on the basis of the EICV surveys. They differentiate between 5 categories from low to very high poverty reduction. Our six settings in the Southern Province are located in districts in the lowest 3 categories (so with low to medium poverty reduction). However, the two locations in the Northern Province, in which we cross-checked certain findings in 2013, are located in a district with very high poverty reduction.

${ }^{2}$ In the document, 'Vision 2020' the Republic of Rwanda outlines its vision for the future of Rwanda,see GoR, 2002.

${ }^{3}$ See for an example interview with IMFs chief mission in Rwanda Kristina Kostial by Natalie Hairfield, 'Rwanda's Task: Manage More Aid', July 17, 2007, see http://www.imf.org/external/pubs/ft/survey/so/2007/INT0718A.htm.

${ }^{4}$ For the EDPRS-I policy, launched in 2007, the aim was to translate continued economic growth into considerable poverty reduction. The policy set targets for reducing overall poverty rates from 57 to $46 \%$, and extreme poverty from 37 to $24 \%$ (GoR, 2007: 34 ).

${ }^{5}$ See the website of SIDA, http://www.sida.se/English/where-we-work/Africa/Rwanda/Developments-inRwanda [date last access, 30 October 2014].

${ }^{6}$ In-depth analysis of district data illustrates that the problem of missing youth appears nationwide except for Kigali's districts. The phenomenon is most prominent in Nyamagabe and Kamonyi districts in the Southern province, in Rulindo district in the western province, in Burera district in the northern province, and in Nyagatare district in the Eastern province (own calculations based on GoR (2013), EICV District profiles, online at: http://www.statistics.gov.rw/survey-period/integrated-household-living-conditions-survey-3-eicv-3.

${ }^{7}$ Nonresponse occurs when persons included in the sample refuse to participate or forget to respond to certain questions.

${ }^{8}$ The organisation of agricultural activities in marshlands had by 2011 undergone radical change. Around 20052007, the national government mandated the local administration to allocate wetland plots to farmers' associations. These associations have recently (2009-2011) been urged to group themselves into officially recognized cooperatives. Moreover, cultivation practices have also changed. Crop diversification (combination of different crop types on the same plot of land) is no longer permitted; instead cooperatives concentrate on market-oriented 'high-value' crops such as rice, sugar cane, maize, etc. Crops are planted in monocropping arrangements, and cooperative members cultivate and harvest together (Ansoms et al., 2014).

${ }^{9}$ The average number of hours spent per week in off-farm jobs is 39.7 hours for wage earners outside farming (median 40.0 hours), and 25.8 hours for independent non-farmers (median 18 hours). This is significantly higher than the average number of hours worked by wage earners from farming (18.8 hours; median: 15 hours), and by independent farmers (17.0 hours; median: 15.0 hours) (NISR, 2012D: 13).

${ }^{10}$ Formal non-farm employment as a share of total non-farm employment increased mildly from 18 to $20 \%$ between 2007/8 and 2010/11. The average number of workers per enterprise decreased from 2.7 to 2.3 persons per establishment (see table 5).
} 


\section{Bibliography (a couple of references are not mentioned for anonymity purposes)}

Agutamba, K. 2015. "We have no doubt in Rwanda's figures - says IMF chief." New Times, 5 November 2015, www.newtimes.co.rw/section/article/2015-11)05/194120.

Ansoms, A., Wagemakers, I., Walker, M. and Murison, J. 2014 "Land contestation at the micro scale: Struggles for space in the African marshes." World Development 54: 243-252.

Ansoms, A. and D. Rostagno. 2012. "Rwanda's Vision 2020 halfway through: What the eye does not see." Review of African Political Economy 39 (133): 427-450.

Ansoms, A. 2008. "Striving for growth, bypassing the poor? A critical review of Rwanda's rural sector policies.” Journal of Modern African Studies 46 (1): 1-32.

Ansoms, A. 2012 "From 'disaster tourist' to 'transfer gate': (Self)perception of the role of research in rural Rwanda", in: .S Thomson, Ansoms, A. and J. Murison (eds.), Emotional and Ethical Challenges for Field Research in Africa, Palgrave.

Appleton, S. and D. Booth. 2005. "Combining Participatory and Survey-based Approaches to Poverty Monitoring and Analysis." Q-Squared Working Paper No.14, https://www.trentu.ca/ids/documents/Q2_WP14_AppletonandBooth.pdf.

Bethlehem, J., Cobben, F., Schouten, B. 2011. Handbook of Nonresponse in Household Surveys. Wiley, Sussex.

Booth, D. and F. Golooba-Mutebi. 2012. "Developmental patrimonialism? The case of Rwanda." African Affairs 111 (444): 379-403.

Carr-Hill, R. 2014. "Measuring development progress in Africa: the denominator problem." Canadian Journal of Development Studies 35 (1): 136-154.

Casse, T., Jensen, S. 2009. "Do We Understand the Linkages between Economic Growth, Poverty Targets and Poverty Reduction?" Review of African Political Economy, 36 (122): 539-553.

Chemouni, B. 2014. "Explaining the Design of the Rwandan Decentralization: Elite Vulnerability and the Territorial Repartition of Power." Journal of East African Studies, 8(2): 246-262.

Cioffo, G.D. and A. Ansoms. forthcoming. "Modernising agriculture through a 'new' Green Revolution: The limits of the crop intensification program in Rwanda", Review of African Political Economy.

Cioffo, G. D. 2014. "Les petits agriculteurs face à la modernisation rurale dans la Province du Nord du Rwanda : consolidation de l'usage des terres, distribution d'intrants améliorés et sécurité alimentaire." Annuaire de l'Afrique des Grands Lacs 2014-2015, L'Harmattan, Paris.

Deaton, A. 1997. The Analysis of Household Surveys: A Microeconometric Approach to Development Policy. Washington, World Bank.

De Lame, D. 2005. A Hill among a Thousand: Transformations and Ruptures in Rural Rwanda. The University of Wisconsin Press and Royal Museum for Central Africa. 
Department for International Development (DFID). 2012. Operational Plan DFID Rwanda. Updated version June 2012,

https://www.gov.uk/government/uploads/system/uploads/attachment_data/file/67358/rwanda2011.pdf.

FAO. 2008. Deriving Food Security Information from National Household Budget Surveys. Rome, FAO, http://www.fao.org/3/a-i0430e.pdf

Fewsnet. 2005. Rwanda Food Security Update - December 2005. www.fews.net.

Fewsnet. 2006. Rwanda Food Security Update - February 2006. www.fews.net

Gaynor, N. 2014. "“A nation in a hurry': the costs of local governance reforms in Rwanda, Review of African Political Economy, 41(1), 49-63.

Germain, N. 2015. "Rwanda accused of manipulating poverty statistics", France24, 2 November 2015,

http://www.france24.com/en/20151102-rwanda-accused-manipulating-poverty-statistics.

Gökgür, N. 2012. "Rwanda's ruling party-owned enterprises: Do they enhance or impede development?", IOB Discussion Papers 2012.03. Antwerp: Institute of Development Policy and Management.

Government of Rwanda. 2012. Economic Development and Poverty Reduction Strategy 20132018. Kigali, Government of Rwanda

Government of Rwanda. 2007. Economic Development and Poverty Reduction Strategy 20082012. Kigali, Government of Rwanda.

Government of Rwanda. 2005. Organic law $N^{\circ}$ 08/2005 of 14/07/2005 determining the use and management of land in Rwanda. Kigali, Government of Rwanda,

Government of Rwanda. 2002. Rwanda Vision 2020, Kigali, Government of Rwanda.

Gutierrez, T., Krings, G., Blondel, V.D. 2013. "Evaluating socio-economic state of a country analysing airtime credit and mobile phone datasets. http://arxiv.org/pdf/1309.4496.pdf.

Huggins, C. 2014. "Curbs on Land Rights in Rwanda: The 'bundle of rights in context'." Brief - Focus on Land in Africa, www.focusonland.com.

Huggins, C. 2013. "Consolidating land, consolidating control: State-facilitated 'agricultural investment' through the 'Green Revolution in Rwanda.' LDPI working paper 16.

Hurst, E., Li, G., Pugsley, B. 2014. “Are Household Surveys Like Tax Forms? Evidence from Income Underreporting of the Self-Employed." The Review of Economics and Statistics 96 (1): 19-33.

IMF. 2013A. "Statement by the IMF Mission at the Conclusion of its Visit to Rwanda." Press Release No. 13.379, 1 October 2013, www.imf.org.

IMF. 2013B. "2013 Article IV Consultation - The Federal Democratic Republic of Ethiopia." IMF Country Report No. 13/308, Washington, IMF. 
Ingelaere, B. 2010. "Peasants, power and ethnicity: A bottom-up perspective on Rwanda's political transition”, African Affairs 109 (435): 273-292.

Jerven, M. 2013A. Poor Numbers: How we are misled by African development statistics and what to do about it. Cornell, Cornell University Press.

Jerven, M. 2013B. "For richer, for poorer: GDP revisions and Africa's statistical tragedy." African Affairs 112 (446): 138-147.

Kingdom of the Netherlands. 2014. Multi-Annual Strategic Plan 2014-2017 Rwanda. Embassy of the Netherlands, Kigali.

Leegwater, M. 2011, "Sharing Scarcity: Issues of Land Tenure in South-east Rwanda." In Ansoms, A. \& S. Marysse (eds.) Natural resources and local livelihoods in the Great Lakes Region: A Political Economy Perspective. London: Palgrave McMillan.

Michel, L. 2013. "The Rwandan example" (title translated). De Standaard, 26 September 2013, www.standaard.be.

Musahara, H. and C. Huggins. 2005. "Land Reform, Land scarcity and Post-conflict Reconstruction: a case Study of Rwanda”, in Huggins, C. ans J. Clover (eds), From the Ground Up: Land Rights, Conflict and Peace in Sub-Saharan Africa. Institute of Security Studies.

McKay, A. and M. Verpoorten. forthcoming. "Growth, poverty reduction and inequality in Rwanda", unpublished paper.

National Institute of Statistics of Rwanda. 2015. Rwanda Poverty Profile Report 2013/2014: Results of Integrated Household Living Conditions Survey. Kigali, NISR, 42 p.

National Institute of Statistics of Rwanda. 2012. The Evolution of Poverty in Rwanda from 2000 to 2011: Results from the Household Surveys (EICV). Kigali, NISR, 38 p.

National Institute of Statistics of Rwanda. 2012 A. The Third Integrated Household Living Conditions Survey (EICV3): Main Indicators Report. Kigali, NISR, 206 p.

National Institute of Statistics of Rwanda. 2012 B. EICV Thematic Report - Youth. Kigali, NISR, $40 \mathrm{p}$.

National Institute of Statistics of Rwanda. 2012 C. EICV Thematic Report-Agriculture. Kigali, NISR, 40 p.

National Institute of Statistics of Rwanda. 2012D. EICV Thematic Report - Economic Activity. Kigali, NISR, 60 p.

National Institute of Statistics of Rwanda. 2012E. Rwanda Demographic and Health Survey: Final report. Kigali, NISR, 546 p.

Newbury, C. 2011. "High modernism and the ground level: the imidugudu policy in Rwanda". In S. Straus and L. Waldorf (eds) Remaking Rwanda: state building and human rights after mass violence. Madison, WI: Wisconsin University Press, 223-239. 
OECD. 2014. How was life? Global well-being since 1820. OECD, www.oecd.org.

Olivier de Sardan J.-P. 2008. La rigueur du qualitatif. Les contraintes empiriques de l'interprétation socio-anthropologique. Louvain-la-Neuve, Academia-Bruylant.

Purdekova, A. 2012. "Rendering Rwanda Governable: Order, Containment and Cleansing in the Rationality of Post-genocide Rule.” L'Afrique des Grands Lacs: Annuaire, 2012-2013, L'Harmattan, Paris.

Reyntjens, F. 2015. "Lies, damned lies and statistics: Poverty reduction Rwandan-style and how the aid community loves it", Blog of 3 November 2015 posted on www.africanarguments.org.

Reyntjens, F. 2013. Political Governance in Post-Genocide Rwanda. Cambridge: Cambridge University Press.

Rugira, L. 2014. "When 'tekiniki' goes sour." New Times, October 2014, seehttp://www.newtimes.co.rw/section/article/2014-10-20/182126/

Schwartz, N. 2007. "Cognitive Aspects of Survey Methodology." Applied Cognitive Psychology 21: 277-287.

Sommers, M. 2012. Stuck: Rwandan Youth and the Struggle for Adulthood. Georgia: University of Georgia Press.

Thomson, S. 2013. "Whispering truth to power: Everyday resistance to reconciliation in postgenocide Rwanda.” Madison: University of Wisconsin Press.

United Nations Development Program. 2007. "Turning Vision 2020 into Reality: From Recovery to Sustainable Human Development". National Human Development Report Rwanda, UNDP.

Van Damme, J., A. Ansoms and P. Baret. 2014. "Agricultural innovation from above and from below: Confrontation and integration on Rwanda's hills." African Affairs 113 (450): 108-127.

Versailles, B. 2012. Country Learning Notes: Rwanda performance contracts (imihigo). London, ODI.

Wallace, J. 2014. "Juking the Stats? Authoritarian Information Problems in China." British Journal of Political Sciences, forthcoming.

Wang, X. \& Woo W.T. 2011. "The Size and Distribution of Hidden Household Income in China." Asian Economic Papers 10 (1): 1-26.

World Bank. 2016. Doing Business 2016: Measuring Regulatory Quality and Efficiency. Washington, World Bank.

World Bank. 2015. World Bank Development Indicators. World Bank, databank.worldbank.org. 
